\title{
The effects of bioactive compounds on biomarkers of obesity
}

\author{
Rebecca Coats and Danik Martirosyan
}

Functional Food Center/Functional Food Institute, Dallas, TX 75252, US

Corresponding Author: Danik Martirosyan, PhD, Functional Food Center/Functional Food Institute, 7575 Frankford Rd, Suite 3527, Dallas, TX 75252, USA

Submission Date: September 03, 2015, Acceptance date: November 22, 2015: Publication date: November 28, 2015

\begin{abstract}
:
The world is presently facing a prolonged struggle without a predictable cure. Obesity causes hundreds of thousands of fatalities each year, along with holding a position as a primary contributor to several other virulent chronic diseases. This review of scientific literature will examine the current state of obesity along with the mechanisms and biomarkers that lay the foundation for the development of the disease. Furthermore, this article will assess several functional foods and the bioactive compounds they contain that play an influential role in the prevention and treatment of obesity as a chronic disease. By presenting many relevant functional food research studies, this review aims to offer auxiliary support to traditional obesity treatments. The topic of functional foods and their relation to obesity is an extremely important topic to explore due to the severe expansion of obesity in the past few decades. Overall, the purpose of this review is to supply a comprehensive description of obesity and examine results of functional foods in clinical trials that may offer innovative benefits.
\end{abstract}

Keywords: obesity, bioactive compounds, disease, health, functional foods, clinical trials

\section{INTRODUCTION:}

While it is indisputable that the spotlight on the obesity epidemic has been intensifying in recent years, obesity is by no means a new issue. In fact, obesity has posed a major problem since the 1950's and has been growing every decade since. The prevalence of this disease remained relatively unchanged throughout the 1960's and 70's, however it endured a sharp incline in the 80 's [1]. Policy makers have been trying to halt the growth of obesity through advocating healthy foods and exercise while discouraging junk food and sedentary lifestyles, however it can be argued that the magnitude of obesity calls for a more combative resolution strategy.

While the idea of eating ample fruits and vegetables has always been common health advice, studies on bioactive compounds have emerged in recent years to discover exactly which components in the foods are responsible for the positive effects. Bioactive compounds are defined as non-nutritive ingredients that provide important benefits to maintain health. Bioactive compounds including flavonoids, carotenoids and vitamins all work together in order to create functional foods [2]. 
Functional foods began their rise in popularity around the same time obesity began gaining prevalence: in the 1980's. Japan is often regarded as the birthplace of functional foods as they are recognized today, however several Asian countries have deep running traditions in using food for medicinal and health benefits [3]. In Japan, functional foods are regulated by the government and must meet certain qualifications and guidelines in order to obtain their status as a functional food, or as they are referred to there: Foods for Specific Health Uses [4]. In the United States, functional foods are not as formalized; however, the FDA does have certain guidelines for foods making health claims or nutrient content claims. For instance, in order for foods to make health claims, there must be sufficient evidence that prove that the food is tied to the health function it alleges to be. $[3,4]$. The growing popularity of bioactive compounds and functional food in this modern age provides a new option for fighting the current state of obesity.

\section{RETRIEVAL OF PUBLISHED STUDIES:}

Electronic searches of published studies were conducted utilizing PubMed®, Google Scholar, and EBSCOhost. Both review and research papers were included. Eligible articles provided relevant, scientific research on various bioactive compounds in functional foods and their effects on obesity biomarkers. No language limitations were imposed. Keywords for the search included: obesity, functional food, biomarkers, bioactive compounds, vitamins, fiber, polyphenols, green tea, plant sterols, beta-glucans, mechanisms, antioxidants, health, history, omega-3 fatty acids, treatment, diabetes, risk, cholesterol, hypertension, macrophages, leptin, cytokines, inflammation and adinopectin.

\section{MODERN STATUS OF OBESITY:}

Obesity is currently one of the most critical medical issues in the world due in part to its role as a key contributing factor to many chronic and fatal diseases. Characterized by a BMI of greater or equal to $30 \mathrm{~kg} / \mathrm{m}^{2}$, obesity is contrasted by a healthy BMI range of 18.5-24.9 and an overweight BMI range of 25-29.9. Since 1980, the prevalence of obesity has more than doubled; today, out of the 1.9 billion adults who are overweight, 600 million of them are obese. This translates to about $13 \%$ of all adults worldwide suffering from obesity [5].

Table 1. Countries with highest obesity prevalence*

\begin{tabular}{|l|l|l|l|}
\hline Country & \% Obese adults & \% Men & \% Women \\
\hline United States & 36.3 & 33.9 & 35.6 \\
\hline Mexico & 32.4 & 25.8 & 37.5 \\
\hline New Zealand & 31.3 & 30.3 & 32.2 \\
\hline Hungary & 28.5 & 25.3 & 30.4 \\
\hline Australia & 28.3 & 28.4 & 28.2 \\
\hline Canada & 25.4 & 28.2 & 24.6 \\
\hline Chile & 25.1 & 19.2 & 30.7 \\
\hline United Kingdom & 24.7 & 24.4 & 25.1 \\
\hline Ireland & 23 & 22 & 24 \\
\hline Luxembourg & 22.7 & 24.1 & 21 \\
\hline
\end{tabular}

(*All info is measured data based on adults aged 15 and over. Modified from Organization for Economic Cooperation and Development. OECD Health and Statistics 2014 [47].) 
The United States leads in number of obese citizens over 15 years old, however there are many countries with percentages in the 20's and 30's. These numbers have been increasing for decades and will only continue to grow until effective changes are made.

While obesity's effects extend across all ethnicities of both men and women, some demographics are affected more frequently than others. The table shows that in seven out of the top ten countries, the percentage of obese women is higher than the percentage of men. Moreover, research shows both African American and Mexican women have a higher prevalence of obesity than Caucasian women [6]. Much of this can be attributed to traditional foods of these backgrounds being high in fat and calories, however genetics may play an important part as well.

Finding a successful strategy for overcoming the obesity epidemic is unquestionably crucial, partly because the costs of obesity are extremely detrimental. Currently, obesity accounts for about $2-7 \%$ of all healthcare costs, making it a multi-billion dollar drain on the economy [5]. In fact, in the United States alone, \$147 billion dollars were attributed to the disease in 2008 [7]. On an individual level, healthcare costs generally increase as BMI increases, which explains why medical costs for obese people average $\$ 1429$ higher than non-obese people each year [7, 8].

Clearly, obesity is remarkably expensive, but the costs of the disease are not solely monetary. Obesity is one of the most prominent risk factors in a myriad of other health problems including diabetes, cancer, liver disease, sleep apnea, cognitive dysfunctions, CVD, and dyslipidemia [6]. These are a few of the most prevalent and costly diseases seen throughout the world. Additionally, according to the National Health and Nutrition Examination Survey (NHANES), obesity claims an excess of 112, 000 lives annually when compared to those with a healthy BMI [9].

Table 2. Diseases associated with obesity

\begin{tabular}{|l|l|l|l|l|}
\hline Disease & Prevalence & Complications & Mortalities & Reference \\
\hline CVD & n/a: & $\begin{array}{l}\text { Heart disease, } \\
\text { stroke, blood clots, } \\
\text { aneurysm, cardiac } \\
\text { arrest }\end{array}$ & $\begin{array}{l}\text { Most common cause } \\
\text { of death: 17.5 million } \\
\text { globally in 2012 }\end{array}$ & WHO, 2015 [53] \\
\hline Diabetes & $\begin{array}{l}387 \text { million } \\
\text { people worldwide }\end{array}$ & $\begin{array}{l}\text { CVD, nerve } \\
\text { damage }\end{array}$ & $\begin{array}{l}4.9 \text { million globally in } \\
2014\end{array}$ & IDF, 2014 [52] \\
\hline Hypertension & $\begin{array}{l}1 \text { billion people } \\
\text { worldwide }\end{array}$ & $\begin{array}{l}\text { Heart attack, } \\
\text { stroke, kidney } \\
\text { disease }\end{array}$ & 7.1 million globally & $\begin{array}{l}\text { Dreisbach, 2014 } \\
\text { [54] }\end{array}$ \\
\hline Cancers & $\begin{array}{l}32.5 \text { million } \\
\text { people worldwide }\end{array}$ & $\begin{array}{l}\text { Many types } \\
\text { including lung, } \\
\text { breast, colon, } \\
\text { prostrate, bowel, } \\
\text { etc. }\end{array}$ & $\begin{array}{l}8.2 \text { million globally in } \\
2012\end{array}$ & $\begin{array}{l}\text { Cancer Research } \\
\text { UK, [55] }\end{array}$ \\
\hline
\end{tabular}

Highlighted above are just a few of the many diseases correlated with obesity. There are 37.7 million global deaths a year among these four diseases exclusively, so it is clear the immense burden obesity plays on the death rates of the human race. Cardiovascular disease, for instance, has an innumerable amount of complications including heart disease and cardiac arrest. With 17.5 million people dying from this disease, it is not hard to see why obesity is killing so 
many people. Additionally, various complications and fatalities that result from different forms of cancer are widely documented in the medical and general populations. With such a large portion of people dying from these obesity-linked diseases, it puts into perspective how impactful obesity truly is.

It is easy to see that this disease poses many global obstacles. The world is in urgent need of a resolution, but before that can occur, it is necessary to fully understand the infrastructure of how obesity develops and what exactly it does to the body.

\section{MECHANISMS OF OBESITY:}

Like any disease, it is difficult to completely understand the specific pathopsychological mechanisms that occur in obesity. First and foremost, obesity is the result of an excess accumulation of visceral (abdominal) fat in the body. Visceral adipose tissue produces a greater number of pro-inflammatory cytokines compared to subcutaneous fat [10]. Cytokines such as Interleukin-6 and tumor necrosis factor-alpha trigger chronic, low grade inflammation in the body, which is a key component in characterizing obesity [11].

As previously discussed, obesity does not affect all people equally. Rates of visceral fat accumulation differ among demographics, some of the more prominent being Caucasian men and African American women [10]. As this visceral adipose tissue accumulates, macrophages progressively accumulate as well. These macrophages are found more frequently in visceral fat and, being phagocytic cells, they aid in the increased inflammation seen in obese patients.

Another obesity mechanism to examine is the role of leptin. Leptin is a hormone produced by adipose tissue in the body to aid in regulating satiety. Leptin is often referred to as the "appetite suppressing hormone" while its paradox, ghrelin, is known as the "hunger hormone." Studies have shown that people suffering from obesity have lower satiety responsiveness than non-obese people [12]. In other words, these people do not feel full after the same amount of food that would cause a non-obese person to feel full. This is the result of a mutation in the leptin gene, which leads to early onset obesity.

An increased number of macrophages and a less effective leptin hormone work together to create optimal conditions for obesity to develop and prosper. Inflammation and lower satiety are both important mechanisms for this disease, however these mechanisms can be understood further through the specific biomarkers of obesity.

\section{BIOMARKERS OF OBESITY:}

Obesity is a complex disease with many different factors contributing to its overall condition. As discussed earlier, the primary biomarkers for obesity are the up-regulated pro-inflammatory cytokines and chemokines. Examples of these include TNF-alpha, ICAM-1, IL-6 and V-CAM-1. Together, these work to increase inflammation in the body while antioxidants and other antiinflammatories are down regulated [13].

Free fatty acids (FFA's) are also more easily available in those who are obese. They are produced in excess while the adipocytokines alter inflammatory responses in the body. FFAs contribute to vasoconstriction of blood vessel cells, which ultimately leads to atherosclerosis, or the accumulation of "plaque" from fats and cholesterol on the artery wall [14]. This explains the association between obesity and coronary artery disease (CAD) [13]. 
Inflammation is an important obesity indicator, but there are several other significant biomarkers of this disease. Insulin resistance and impaired glucose tolerance are two additional indices that are frequently seen in people with obesity [15]. In addition to FFA's and CAD, these two biomarkers explain why obesity is so tightly linked with T2D.

Another primary biomarker of obesity is adiponectin. This is a highly significant protein because it is majorly involved in moderating and regulating glucose as well as breaking down fatty acids. It is secreted by adipocytokines and has been shown to be present in lower amounts in people diagnosed with diabetes, CAD, insulin resistance, and atherosclerosis [16]. Many studies have been done on adinopectin that indicate it is significantly related to body weight. Moreover, studies have also shown that improving insulin resistance also improves adinopectin concentrations. This protein is a key factor in regulating obesity and the many complications that come with it [17].

It is imperative to recognize and understand the many biomarkers of obesity because they all play a relevant part in the disease and its devastation. Once the biomarkers have been specified, the next step in comprehending obesity is to explore the bioactive compounds that may aid in combatting the disease.

\section{BIOACTIVE COMPOUNDS AND OBESITY:}

Because rates of obesity have been inclining at such alarming rates, plant based diets have grown in popularity due to their bountiful health advantages. Many plants and plant-based foods contain bioactive compounds that may offer obesity-fighting benefits further than their nutritive value alone.

\section{Vitamins}

Some of the most well known bioactive compounds are vitamins. Found in many different plant bases foods, vitamins offer several benefits to help counteract obesity.

Table 3. Effects of different vitamins on obesity biomarkers

\begin{tabular}{|c|c|c|c|c|c|c|}
\hline Vitamin & Type & Benefits & $\begin{array}{l}\text { Foods Found } \\
\text { In }\end{array}$ & $\begin{array}{l}\text { Uses in Clinical } \\
\text { Trial }\end{array}$ & Outcome & Reference \\
\hline A & Fat Soluble & $\begin{array}{l}\text { Neural cell } \\
\text { growth, } \\
\text { immune } \\
\text { function, } \\
\text { vision, } \\
\text { adipose tissue } \\
\text { regulation }\end{array}$ & $\begin{array}{l}\text { Sweet } \\
\text { potatoes, } \\
\text { carrots, dark } \\
\text { leafy greens }\end{array}$ & $\begin{array}{l}4 \text { month trial } \\
\text { with } 25,000 \mathrm{IU} \\
\text { daily } \\
\text { supplementation } \\
\text { in } 84 \text { women } 17- \\
50 \text { years }\end{array}$ & $\begin{array}{l}\text { Decrease in } \\
\text { serum thyroid } \\
\text { stimulating } \\
\text { hormone and } \\
\text { serum retinol } \\
\text { binding } \\
\text { protein }\end{array}$ & $\begin{array}{l}\text { Farhangi, } \\
2012 \text { [48] }\end{array}$ \\
\hline $\bar{D}$ & Fat Soluble & $\begin{array}{l}\text { Bone health, } \\
\text { metabolism }\end{array}$ & $\begin{array}{l}\text { Poultry, fish, } \\
\text { nuts, beans }\end{array}$ & $\begin{array}{l}12 \text { month trial } \\
\text { with } 2000 \mathrm{IU} \\
\text { daily } \\
\text { supplementation } \\
\text { in } 218 \\
\text { overweight/obese } \\
\text { patients }\end{array}$ & $\begin{array}{l}\text { Decreased } \\
\text { weight and \% } \\
\text { body fat by } \\
10.6 \% \text { and } \\
9.9 \% \text {, } \\
\text { respectively }\end{array}$ & $\begin{array}{l}\text { Mason, } \\
2014 \text { [49] }\end{array}$ \\
\hline $\mathrm{C}$ & Water soluble & Immune & Oranges, bell & 4 month trial & Reduced & Murer, \\
\hline
\end{tabular}




\begin{tabular}{|c|c|c|c|c|c|c|}
\hline Vitamin & Type & Benefits & $\begin{array}{l}\text { Foods Found } \\
\text { In }\end{array}$ & $\begin{array}{l}\text { Uses in Clinical } \\
\text { Trial }\end{array}$ & Outcome & Reference \\
\hline & & $\begin{array}{l}\text { function, } \\
\text { wound } \\
\text { healing, } \\
\text { tissue repair }\end{array}$ & $\begin{array}{l}\text { peppers, kiwi, } \\
\text { broccoli }\end{array}$ & $\begin{array}{l}\text { with } 500 \mathrm{mg} \\
\text { daily } \\
\text { supplements in } \\
23 \\
\text { obese/overweight } \\
\text { children }\end{array}$ & $\begin{array}{l}\text { oxidative } \\
\text { stress by } \\
>30 \% \text { and } \\
\text { improved } \\
\text { antioxidant } \\
\text { status }\end{array}$ & $2014[50]$ \\
\hline B-9 & Water soluble & $\begin{array}{l}\text { Nerve cell } \\
\text { function, } \\
\text { DNA } \\
\text { production }\end{array}$ & $\begin{array}{l}\text { Lentils. } \\
\text { Spinach, bread } \\
\text { avocado }\end{array}$ & $\begin{array}{l}2 \text { month trial } \\
\text { with } 5 \text { mg daily } \\
\text { supplementation } \\
\text { in } 50 \text { obese } \\
\text { children }\end{array}$ & $\begin{array}{l}\text { Plasma } \\
\text { homocysteine } \\
\text { levels } \\
\text { decreased by } \\
15.75 \%\end{array}$ & $\begin{array}{l}\text { Iamopas. } \\
2014 \text { [51] }\end{array}$ \\
\hline $\mathrm{E}$ & Fat soluble & $\begin{array}{l}\text { Tissue } \\
\text { protection } \\
\text { from free } \\
\text { radicals }\end{array}$ & $\begin{array}{l}\text { Sunflower } \\
\text { seeds, spinach, } \\
\text { almonds }\end{array}$ & $\begin{array}{l}12 \text { week trial } \\
\text { with } 400 \text { IU }(+3 \\
\text { cups of green } \\
\text { tea) } \\
\text { supplementation } \\
\text { in elderly } \\
\text { patients with a } \\
\text { BMI of } 28+\end{array}$ & $\begin{array}{l}\text { Waist } \\
\text { circumference } \\
\text { decreased by } \\
3.9 \mathrm{~cm} \text { in } \\
\text { men and } 10.7 \\
\mathrm{~cm} \text { in women, } \\
\text { respectively } \\
\text { along with } \\
\text { decreased } \\
\text { fasting } \\
\text { glucose levels } \\
(5.30 \text { to } 4.98 \\
\text { mmol/L) }\end{array}$ & $\begin{array}{l}\text { Narotski, } \\
2013 \text { [56] }\end{array}$ \\
\hline
\end{tabular}

Vitamins have gained popularity for their extensive benefits within the human body. These five vitamins highlight some of the weight management benefits they provide when taken in adequate dosages.

Vitamin D for example, was able to decrease weight and body fat percentage by significant amounts in obese patients over a 12-month trial. While the participants of this trial were also following a reduced-calorie diet, the group taking the Vitamin D supplement saw a weight loss of $10.6 \%$ as opposed to the $8.7 \%$ loss in the placebo group, providing evidence of Vitamin D's effectiveness when used as a supplement in conjunction with diet alterations [49].

A clinical trial studying the effects of vitamin B-9, also known as folic acid, on 50 obese children showed a $15.8 \%$ decrease in blood homocysteine levels over 2 months. This is an important study because homocysteine is an amino acid directly related to heart disease- a known risk factor of obesity. Incorporating folic acid into the diet may be an efficient way to lower plasma homocysteine levels and thereby lower risk of heart disease [51].

Additionally, Farhangi et al studied vitamin A in women and found a decrease in serum thyroid stimulating hormone, which helped create an uptake in metabolism [48]. Murer et al found adequate supplementation of vitamin $\mathrm{C}$ in overweight children reduced oxidative stress: a biomarker of obesity linked to inflammation [50]. Lastly, Narotski et al found that vitamin E supplementation in elderly patients aided in waist circumference and decreased fasting glucose levels [56]. 
These, along with countless other studies, verify the boundless opportunities vitamins can offer against obesity.

\section{Red Wine and Green Tea: Powerful Drinks}

Another example of a bioactive compound found in plants is the polyphenol resveratrol, which comes from grapes. Resveratrol, made popular due to its presence in red wines, has been shown to increase adinopectin and thereby decrease inflammation [18]. Similarly, numerous bioactive compounds can be found in another popular drink: herbal teas. Green tea, specifically, contains a multitude of bioactive compounds that may fight against obesity. Catechins such as epigallocatechin-3-gallate (EGCG) found in green tea have shown positive results on weight loss, especially when consumed in conjunction with caffeine. These catechins increase fat oxidation and energy expenditure: both very useful in battling obesity [19]. Furthermore, catechins in green tea aid in increasing thermogenesis, reducing fat absorption and increasing satiety [20]. Overall, green tea has the power to improve overall antioxidant status within habitual drinkers [21].

Table 4. Green tea catechin effects on obesity biomarkers

\begin{tabular}{|c|c|c|c|c|c|c|}
\hline Reference & $\mathrm{N}$ & Patients & Intervention & Outcome & Duration & Study \\
\hline $\begin{array}{l}\text { Basu, } 2011 \\
{[41]}\end{array}$ & $\begin{array}{l}41 \\
\text { initial } \\
35 \\
\text { final }\end{array}$ & $\begin{array}{l}\text { Patients } \\
\text { with } \\
\text { metabolic } \\
\text { syndrome }\end{array}$ & $\begin{array}{l}4 \text { cups tea/day or } \\
2 \text { capsules }+4 \\
\text { cups water/day } \\
\text { both contained } \\
\sim 440 \mathrm{mg} \text { EGCG }\end{array}$ & $\begin{array}{l}\text { Decreased IL-6 } \\
\text { levels by } 37 \% \text { and } \\
\text { serum amyloid alpha } \\
\text { levels by } 14.4 \%\end{array}$ & 8 weeks & $\begin{array}{l}\text { Randomized } \\
\text { controlled } \\
\text { trial }\end{array}$ \\
\hline $\begin{array}{l}\text { Venables, } \\
2008 \text { [42] }\end{array}$ & 12 & $\begin{array}{l}\text { Healthy } \\
\text { males }\end{array}$ & $\begin{array}{l}30 \text { minute cycling } \\
\text { exercise before } \\
\text { and after green } \\
\text { tea extract } \\
\text { supplement } \\
\text { containing } 366 \mathrm{mg} \\
\text { EGCG }\end{array}$ & $\begin{array}{l}\text { Fat oxidation rates } \\
17 \% \text { higher after } \\
\text { supplementation }\end{array}$ & $24 \mathrm{hr}$ & Clinical trial \\
\hline $\begin{array}{l}\text { Brown, } 2009 \\
{[43]}\end{array}$ & $\begin{array}{l}100 \\
\text { initial } \\
88 \\
\text { final }\end{array}$ & $\begin{array}{l}\text { Males } 40-65 \\
\text { with a BMI } \\
\text { between } 28- \\
38\end{array}$ & $\begin{array}{l}\text { 800mg EGCG } \\
\text { /day }\end{array}$ & $\begin{array}{l}\text { Reduced diastolic bp } \\
\text { by } 2.5 \mathrm{~mm} / \mathrm{hg} \text { and } \\
\text { systolic bp by } 2.8 \\
\mathrm{~mm} / \mathrm{hg}\end{array}$ & 8 weeks & $\begin{array}{l}\text { Randomized } \\
\text { controlled } \\
\text { trial }\end{array}$ \\
\hline $\begin{array}{l}\text { Maki, } 2009 \\
{[44]}\end{array}$ & $\begin{array}{l}132 \\
\text { initial } \\
107 \\
\text { final }\end{array}$ & $\begin{array}{l}\text { Sedentary } \\
\text { men and } \\
\text { women with } \\
\text { a BMI } \\
\text { between 25- } \\
40\end{array}$ & $\begin{array}{l}500 \mathrm{~mL} \text { green tea } \\
\text { beverage } \\
\text { containing } 625 \\
\text { mg catechins/day } \\
\text { in conjunction } \\
\text { with } 180 \mathrm{~min} \\
\text { moderate } \\
\text { exercise/week } \\
\text { and constant } \\
\text { energy intake }\end{array}$ & $\begin{array}{l}\text { Decreased body } \\
\text { weight by an } \\
\text { average of } 3.1 \mathrm{~kg} \\
\text { and lost } 7.7 \% \\
\text { abdominal fat }\end{array}$ & $\begin{array}{l}12 \\
\text { weeks }\end{array}$ & Clinical trial \\
\hline $\begin{array}{l}\text { Suliburska, } \\
2012 \text { [20] }\end{array}$ & 46 & $\begin{array}{l}\text { Men and } \\
\text { women } \\
\text { between } 30- \\
60 \text { years }\end{array}$ & $\begin{array}{l}\text { One } 379 \mathrm{mg} \text { green } \\
\text { tea extract } \\
\text { capsule } \\
\text { containing } 208\end{array}$ & $\begin{array}{l}\text { Significant reduction } \\
\text { in LDL cholesterol } \\
\text { from } 3.44 \text { to } 3.02 \\
\mathrm{~mm} / \mathrm{hg} \text { and increase }\end{array}$ & $\begin{array}{l}3 \\
\text { months }\end{array}$ & $\begin{array}{l}\text { Randomized } \\
\text { controlled } \\
\text { trial }\end{array}$ \\
\hline
\end{tabular}




\begin{tabular}{|c|c|c|c|c|c|c|}
\hline & & $\begin{array}{l}\text { with a BMI } \\
>30\end{array}$ & mg EGCG/day & $\begin{array}{l}\text { in HDL cholesterol } \\
\text { from } 1.12 \text { to } 1.28 \\
\mathrm{~mm} / \mathrm{hg}\end{array}$ & & \\
\hline $\begin{array}{l}\text { Hsu, } 2011 \\
{[45]}\end{array}$ & $\begin{array}{l}80 \\
\text { initial } \\
68 \\
\text { final }\end{array}$ & $\begin{array}{l}\text { Chinese } \\
\text { men and } \\
\text { women with } \\
\text { a BMI >25 } \\
\text { with } \\
\text { diagnosed } \\
\text { type } 2 \\
\text { diabetes }\end{array}$ & $\begin{array}{l}\text { Daly green tea } \\
\text { extract capsule } \\
\text { containing } 856 \mathrm{mg} \\
\text { EGCG }\end{array}$ & $\begin{array}{l}\text { Reduced systolic BP } \\
\text { by } 1.5 \% \text {, waist } \\
\text { circumference by } \\
3.2 \% \text { and increased } \\
\text { adinopectin levels by } \\
2.0 \%\end{array}$ & $\begin{array}{l}11 \\
\text { months }\end{array}$ & Clinical trial \\
\hline $\begin{array}{l}\text { Dulloo, } 1999 \\
\text { [46] }\end{array}$ & 10 & $\begin{array}{l}\text { Men with } 8- \\
30 \% \text { body } \\
\text { fat }\end{array}$ & $\begin{array}{l}\text { Green tea extract } \\
\text { capsule } \\
\text { containing } 90 \mathrm{mg} \\
\text { EGCG } 3 \\
\text { times/day during } \\
\text { a } 24 \text { hr period in a } \\
\text { respiratory } \\
\text { chamber }\end{array}$ & $\begin{array}{l}4 \% \text { increase in } \\
\text { energy expenditure } \\
\text { and a decrease from } \\
.88 \text { to } .85 \text { in } 24 \text {-hour } \\
\text { respiratory quotient }\end{array}$ & $24 \mathrm{hr}$ & Clinical trial \\
\hline
\end{tabular}

Available in many forms, green tea can provide tremendous benefits on body fat and cholesterol. These seven clinical trials demonstrate just some a few of the positive results that have come from studying catechins in green tea.

Basu et al found 4 cups of green tea a day was able to decrease IL-6 levels and serum amyloid alpha levels- two highly substantial biomarkers of obesity [41]. Venables et al showed that exercising after green tea supplements was $17 \%$ more effective in oxidizing fat than regular exercise [42]. Furthermore, Dulloo et al showed that green tea increased energy expenditure by $4 \%$, which lines up with the study done by Venables et al [46]. Studies such as these two are valuable as they show how bioactive compounds in green tea combined with physical activity can maximize the benefits of both.

Additionally, both Brown et al and Hsu et al found that green tea significantly reduced bloody pressure when supplements contained 800-856 mg EGCG [43,45]. Maki et al studied the effects of green tea on body weight and saw an average decrease of $3.1 \mathrm{~kg}$ along with a $7.7 \%$ decrease in abdominal fat when supplements were used in conjunction with moderate exercise [44]. Finally, Suliburska et al studied the effects the beverage had on cholesterol and discovered a reduction in LDL with an increase in HDL [20]

The capability of the catechins in green tea to fight biomarkers, increase energy expenditure and fat oxidation, reduce blood pressure, body weight, and cholesterol proves it is a highly influential compound and can be used in many sectors of obesity management.

\section{Plant Sterol Esters}

Other bioactive compounds that have been thoroughly studied are plant sterol esters. Plant sterol esters are found in many plant-based foods including vegetable oil, nuts, seeds, grains and leaves. These compounds display positive effects on obesity by lowering LDL cholesterol, one of the most common complications that come with obesity. 
Table 5. The effects of plant sterols on biomarkers of obesity

\begin{tabular}{|c|c|c|c|c|c|c|c|}
\hline References & Analysts & $\mathrm{n}$ & Subject & Duration & Intervention & Outcome & Study \\
\hline $\begin{array}{l}\text { Hongu, } 2014 \\
\text { [27] }\end{array}$ & $\begin{array}{l}\text { Orzya sativa } \\
\text { L. Indica and } \\
\text { wood sterols } \\
\text { in rice snack } \\
\text { bars }\end{array}$ & $\begin{array}{l}31 \\
\text { initial } \\
24 \\
\text { final }\end{array}$ & $\begin{array}{l}\text { Patients with a } \\
\text { BMI between } \\
29-35\end{array}$ & 8 weeks & $\begin{array}{l}0.6 \text { grams } \\
\text { plant sterol } 3 \\
\text { times a day }\end{array}$ & $\begin{array}{l}\text { Average } \\
\text { weight loss of } \\
4.7 \mathrm{~kg} \text { and } \\
\text { loss of total } \\
\text { and LDL } \\
\text { cholesterol }\end{array}$ & $\begin{array}{l}\text { Clinical } \\
\text { trial }\end{array}$ \\
\hline $\begin{array}{l}\text { Theuwissan, } \\
2007 \text { [29] }\end{array}$ & $\begin{array}{l}\beta \text {-glucans and } \\
\text { plant sterols } \\
\text { in muesli }\end{array}$ & $\begin{array}{l}43 \\
\text { initial } \\
42 \\
\text { final } \\
\end{array}$ & $\begin{array}{l}\text { Patients with } \\
\text { elevated } \\
\text { cholesterol }\end{array}$ & 4 weeks & $\begin{array}{l}0.75 \text { g plant } \\
\text { sterol twice a } \\
\text { day }\end{array}$ & $\begin{array}{l}\text { Significantly } \\
\text { lowered LDL } \\
\text { cholesterol by } \\
4.4 \%\end{array}$ & $\begin{array}{l}\text { Clinical } \\
\text { trial }\end{array}$ \\
\hline $\begin{array}{l}\text { Bui, } 2014 \\
\text { [33] }\end{array}$ & $\begin{array}{l}\text { Pregerminated } \\
\text { brown rice } \\
(\text { PGBR) }\end{array}$ & $\begin{array}{l}60 \\
\text { initial } \\
60 \\
\text { final }\end{array}$ & $\begin{array}{l}\text { Vietnamese } \\
\text { women 45-65 } \\
\text { years with } \\
\text { impaired } \\
\text { glucose } \\
\text { tolerance (IGT) }\end{array}$ & 4 weeks & $\begin{array}{l}50 \% \text { of white } \\
\text { rice (WR) } \\
\text { replaced with } \\
\text { PGBR for first } \\
2 \text { wks and } \\
75 \% \text { of WR } \\
\text { replaced in } \\
\text { second } 2 \text { wks } \\
\end{array}$ & 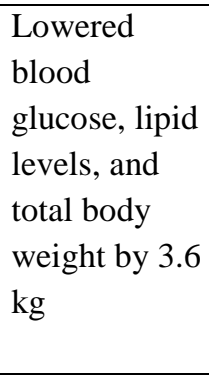 & $\begin{array}{l}\text { Clinical } \\
\text { trial }\end{array}$ \\
\hline $\begin{array}{l}\text { Vásquez- } \\
\text { Trespalacios, } \\
2014 \text { [34] }\end{array}$ & $\begin{array}{l}\text { Yogurt drink } \\
\text { with plant } \\
\text { sterols }\end{array}$ & $\begin{array}{l}40 \\
\text { initial, } \\
40 \\
\text { final }\end{array}$ & $\begin{array}{l}\text { Healthy patients } \\
\text { with } \\
\text { hypercholesterol } \\
\text { emia }\end{array}$ & 4 weeks & $\begin{array}{l}4 \text { g plant } \\
\text { sterols/day }\end{array}$ & $\begin{array}{l}\text { Lowered total } \\
\text { and LDL } \\
\text { cholesterol by } \\
15.6 \text { and } 11.3 \\
\mathrm{mg} / \mathrm{dl} \\
\text { respectively }\end{array}$ & $\begin{array}{l}\text { Clinical } \\
\text { trial }\end{array}$ \\
\hline $\begin{array}{l}\text { Sola, } 2012 \\
{[35]}\end{array}$ & $\begin{array}{l}\text { Cocoa cream } \\
\text { mixed with } \\
\text { hazelnut } \\
\text { cream, } \\
\text { phystosterols, } \\
\text { and soluble } \\
\text { fiber }\end{array}$ & $\begin{array}{l}283 \\
\text { initial, } \\
113 \\
\text { final }\end{array}$ & $\begin{array}{l}\text { Patients with } \\
\text { prehypertension } \\
\text { and stage } 1 \\
\text { hypertension }\end{array}$ & 4 weeks & $\begin{array}{l}2 \mathrm{~g} \text { plant } \\
\text { sterols/day }\end{array}$ & $\begin{array}{l}\text { Decreased } \\
\text { plasma LDL } \\
\text { by } 11.2 \% \text { and } \\
\text { decreased } \\
\text { inflammation }\end{array}$ & $\begin{array}{l}\text { Clinical } \\
\text { trial }\end{array}$ \\
\hline
\end{tabular}

Plant sterols, which can be found in a diverse variety of foods, are extremely beneficial to many biomarkers of obesity. There are many ways to incorporate plant sterols into the diet, which makes them a logical and conducive option for people intending to fight obesity.

The studies done by Hongu et al, Therwissan et al, Vásquez-Trespalacios et al and Sola et al all emphasize on plant sterols' capacity to lower LDL cholesterol- commonly dubbed "bad cholesterol" as a result of its readiness to clog arteries [27. 29. 34, 35]. Additionally, Bui et al showed pregerminated brown rice was successful in lowering both blood glucose and lipid levels, while also decreasing body weight [33]. Hongu et al also support the reduction of body weight from plant sterol supplementation. These studies prove the influence plant sterols can have on mjor obesity biomarkers.

\section{More Bioactive Compounds}

Along with plant sterol esters, beta-glucans are water-soluble fibers that are also commonly found in many plant sources. They are polysaccharides, which help convert cholesterol into bile 
and lower overall cholesterol. Beta-glucans in oat bread, for example, increase nitric oxide consumption [22]. Together, these are two very significant bioactive compounds that may have a future in treating and preventing obesity.

Table 6. The effects of various bioactive compounds on biomarkers of obesity

\begin{tabular}{|c|c|c|c|c|c|c|c|}
\hline Reference & Analysts & $\mathrm{n}$ & Subject & Duration & Intervention & Outcome & Study \\
\hline $\begin{array}{l}\text { Akazome, } \\
2010[36]\end{array}$ & $\begin{array}{l}\text { Apple } \\
\text { polyphenols }\end{array}$ & $\begin{array}{l}94 \text { initial } \\
91 \text { final }\end{array}$ & $\begin{array}{l}\text { Patients } \\
\text { aged 20- } \\
65 \text { with a } \\
\text { BMI } \\
\text { between } \\
25-30\end{array}$ & 12 weeks & $\begin{array}{l}600 \mathrm{mg} \text { of } \\
\text { apple } \\
\text { polyphenols }\end{array}$ & $\begin{array}{l}\text { Lowered } \\
\text { total fat by } \\
\text { an average of } \\
16.3 \mathrm{lbs} \text { and } \\
\text { visceral fat } \\
\text { by } 9.4 \mathrm{lbs}\end{array}$ & $\begin{array}{l}\text { Clinical } \\
\text { trial }\end{array}$ \\
\hline $\begin{array}{l}\text { Egert, } 2010 \\
{[37]}\end{array}$ & $\begin{array}{l}\text { Quercetin } \\
\text { flavonol }\end{array}$ & $\begin{array}{l}96 \text { initial } \\
93 \text { final }\end{array}$ & $\begin{array}{l}\text { Patients } \\
\text { with BMI } \\
\text { between } \\
25-35\end{array}$ & 6 weeks & $150 \mathrm{mg} / \mathrm{day}$ & $\begin{array}{l}\text { Decreased } \\
\text { BP by } \\
3.4 \mathrm{~mm} \mathrm{HG}\end{array}$ & $\begin{array}{l}\text { Clinical } \\
\text { trial }\end{array}$ \\
\hline $\begin{array}{l}\text { Augustine, } \\
2014 \text { [38] }\end{array}$ & $\begin{array}{l}\text { Omega-3 } \\
\text { fatty acid }\end{array}$ & 61 & $\begin{array}{l}\text { Patients } \\
\text { aged } 40- \\
69 \text { with a } \\
\text { BMI } \\
\text { between } \\
25-40\end{array}$ & 16 weeks & $\begin{array}{l}\text { 4g/day omega- } \\
3 \text { fatty acid } \\
\text { ester (P-OM3) }\end{array}$ & $\begin{array}{l}\text { Decreased } \\
\text { LDL by } 2 \\
\mathrm{mg} / \mathrm{dL}\end{array}$ & $\begin{array}{l}\text { Clinical } \\
\text { trial }\end{array}$ \\
\hline $\begin{array}{l}\text { Oosterwerff, } \\
2014 \text { [39] }\end{array}$ & Vitamin D & $\begin{array}{l}130 \text { initial } \\
110 \text { final }\end{array}$ & $\begin{array}{l}\text { Patients } \\
\text { with a } \\
\text { BMI > } 27 \\
\text { with } \\
\text { impaired } \\
\text { fasting } \\
\text { glucose }\end{array}$ & 16 weeks & $\begin{array}{l}\text { 1200 IU/day of } \\
\text { Cholecalciferol } \\
\text { (vitamin D } \\
\text { supplement) }\end{array}$ & $\begin{array}{l}\text { Significant } \\
\text { increase in } \\
\text { insulinogenic } \\
\text { index }\end{array}$ & $\begin{array}{l}\text { Clinical } \\
\text { trial }\end{array}$ \\
\hline $\begin{array}{l}\text { Xiao, } 2014 \\
{[40]}\end{array}$ & $\begin{array}{l}\text { prebiotics } \\
\text { (WTP diet) }\end{array}$ & $\begin{array}{l}123 \text { initial } \\
93 \text { final }\end{array}$ & $\begin{array}{l}\text { Patients } \\
25-55 \\
\text { years with } \\
\text { a BMI > } \\
28\end{array}$ & 9 weeks & $\mathrm{n} / \mathrm{a}$ & $\begin{array}{l}\text { Average } \\
\text { weight loss } \\
\text { of } 5.2 \mathrm{lbs} \\
\text { and average } \\
\text { BMI } \\
\text { decreased } \\
\text { from } 31.5 \text { to } \\
29.8\end{array}$ & $\begin{array}{l}\text { Clinical } \\
\text { trial }\end{array}$ \\
\hline
\end{tabular}

Shown above are a wide variety of bioactive compounds used to counteract obesity. There is a generous collection of functional foods, which offer assistance in staving off obesity and managing it's numerous biomarkers. Research completed by Akazome et al and Xiao et al both highlight bioactive compounds and their effects on body weight. Apple polyphenols and gut microbioatia supplementation resulted in significant body weight reductions in clinical trials. Additionally, quercetin aided in a $3.4 \mathrm{~mm} / \mathrm{hg}$ decrease of blood pressure in patients a trial done by Egart et al.

Overall, these and a surplus of other bioactive compounds have considerable effects within the bodies on which they are consumed. Lowering blood pressure, cholesterol, and body weight are just a few ways these numerous bioactive compounds counteract obesity biomarkers. 
Bioactive compounds are an exciting area of study in the fight against obesity and other diseases because they offer many medicinal and anti-inflammatory benefits that may be useful in halting obesity's exponential growth. This is why bioactive compound-containing functional foods are being studied and examined in labs and clinical trials across the world today.

\section{USAGE OF SOME FUNCTIONAL FOOD PRODUCTS FOR THE MANAGEMENT OF OBESITY IN CLINICAL TRIALS:}

The prospect of using functional foods to prevent and treat obesity is a modern and exciting solution that offers a multitude of opportunities. Today, functional foods are becoming an even more opportune way to manage obesity in light of research that shows exercise and weight management programs alone may not be effective in fighting against obesity. In a 2015 study completed by Fildes et al, data was analyzed for over 176000 obese men and women. After a follow up period of 9 years, it was concluded that the likelihood of reclaiming a normal body weight after being categorized as obese was 1 in 210 for men and 1 in 124 for women [57]. As a world overcome by this highly detrimental disease, these numbers are certainly not good enough to adequately solve this problem. Fortunately, there have been many clinical trials studying the effects of functional foods in obese patients and many positive results have been seen.

In a South African study, the consumption of soy foods was investigated using 90 randomly selected women. These women consumed 40 grams of whole bean soy for 18 months from 20112012. Over this time period, the prevalence of the participants who were overweight decreased from $36 \%$ to $27 \%$. Additionally, the soy consumption lowered LDL cholesterol and increased HDL cholesterol [23].

Another functional food that may have beneficial effects against obesity happens to be a very common one: coffee. According to one study, methylxanthins in coffee and tea have pharmacological effects within the body. Throughout four trials in which participants consumed 3 cups of coffee, several beneficial effects were seen. Firstly, metabolic rates of the participants were increased, which help expedite the process of breaking down food. Additionally, lipid oxidation was increased along with metabolic rate which is an effect seen in green tea as well. Overall, the caffeine in both coffee and tea helped increase available energy and respiratory modifications that proved to be supplementary to weight management and weight loss [24].

Another common class of foods that have health effects beyond their nutritional value is dairy foods. Diary is commonly regarded as having positive health effects on blood pressure. In a study utilizing 76 participants (33 females and 43 males), it was observed that 3 servings of dairy a day had beneficial effects on endothelial function and systolic blood pressure when compared to patients consuming an equally heart healthy diet without dairy [25].

Additionally, the effects of healthy fats, specifically peanuts, have been thoroughly studied. While peanuts are known for being a nutrient-dense food, many people misinterpret this for being unhealthful due to their high calorie and fat content. However, peanuts offer countless benefits and have shown much promise in clinical trials as a functional food. In one study in which people consumed 240 kilocalories worth of peanuts a day, no significant weight gain was actually seen despite the extra calories. The peanuts did, however, promote nitric oxide, as also seen in beta-glucans. This nitric oxide has the potential to lower blood pressure in the body. 
Furthermore, the peanuts lowered triglycerides in the participants. Overall, this food provides a great amount of benefits and when eaten in moderation, can be advantageous in maintaining a healthy weight [26].

Plant sterols, the bioactive compound previously discussed, have also had multiple positive results when used in clinical trials. In one study using healthy males and females between the ages of 21 and 30, snack bars containing rice bran $(\mathrm{RB})$ and rice bran plus plant sterols (RB + PS) were consumed over 8 weeks. At the end of the trial, participants saw a significant decrease in plasma lipid concentration, specifically total cholesterol and LDL cholesterol. There was also an average weight loss of $4.7 \mathrm{~kg}$ in eight weeks [27]. In another study, 351 participants followed a dietary plan containing plant sterols, as well as fiber, soy proteins and nuts, for six months. This dietary portfolio was followed under real world conditions and resulted in improved blood lipid concentrations [28]. Lastly, in a study utilizing men and women with elevated cholesterol levels, it was found that beta glucans and plant sterol esters in museli significantly lowered LDL cholesterol levels by $4.4 \%$ over a 4 -week period [29]. From these studies and others, it is evident that plant sterols have much to offer in the field of functional foods and their use in treating obesity.

The final category of functional foods that will be discussed is fruit. Fruits are widely regarded as being healthy, nutritious foods that can be used to maintain a healthy weight. However, many fruits contain bioactive compounds that can be further used against obesity. One such fruit, sudachi, is a small citrus fruit with several benefits. In a 12-week trial, 40 participants saw improvements in body weight, waist circumference, and serum triglyceride levels after consuming sudachi peel extract [30]. Likewise, adults who consumed freeze-dried strawberries for three months saw a significant decrease in total and LDL cholesterol [31]. Finally, a study examining the effects of Momordica charantia, or bitter melon, showed it prompted lipolysis in human fat cells, improves hyperlipidemia and reduced overall lipid accumulation [32]. These fruits, along with many others, have the capacity to greatly improve health status beyond their dietary content alone.

From these few examples, it is evident that functional foods offer a lot of value towards the fight against obesity. With recent evidence of community weight management programs not working as well as they are intended, it is encouraging to see functional foods provide a multitude of constructive results. It is important to continue researching and evaluating in order to unlock even more amount of information that could potentially change the current status of this epidemic.

\section{CONCLUSIONS:}

Bioactive compounds present in functional foods propose a practical, advantageous approach to obesity. Many have the potential to aid in lowering cholesterol, increasing satiety, and increasing the rate at which fat is oxidized. Together, these are paramount in lowering overall adipose tissue in the body and restoring the body back to a healthy weight. Bioactive compounds in green tea, dairy, fruits and many other plant-based foods have a pervasive capacity to fight against obesity biomarkers like cholesterol, blood pressure, and body fat. Functional foods are an easy and efficient way for the general public to increase their health and fight off obesity in addition to their other lifestyle changes. Used in conjunction with proper diet and exercise, functional foods 
can prominently assist in weight loss and management. Future studies should focus more on finding precise dosages for the highest efficiency of these compounds in their use in weight loss and health renewal.

List of abbreviations: Cardiovascular disease, CVD; body mass index, BMI; low-density lipoprotein, LDL; high-density lipoprotein, HDL; interleukin 6, IL-6; impaired glucose tolerance, IGT; epigallocatechin-3-gallate, EGCG; tumor necrosis factor-alpha, TNF-alpha; intercellular adhesion molecule 1, ICAM-1; vascular cell adhesion molecule 1, V-CAM-1; free fatty acids, FFA; coronary artery disease, CAD; blood pressure, BP; world health organization, WHO; plant sterols, PS; rice bran, RB; pre-germinated brown rice, PGBR; omega-3-acid esters, P-OM3, white rice, WR; type 2 diabetes, T2D; national health and nutrition examination survey, NHANES

Competing Interests: The authors have no financial interests or any other conflicts of interest to disclose.

Authors' Contributions: All authors contributed to this review

\section{REFERENCES:}

1. The Surgeon General's Vision for a Healthy and Fit Nation [http://www.surgeongeneral.gov/priorities/healthy-fit-nation/obesityvision2010.pdf]

2. Patil, B., Jayaprakasha, GK., Chidambara Murthy, KN., Vikram, A.: Bioactive compounds: historical perspectives, opportunities, and challenges. Journal of Agriculture and Food Science. 2009; 57: 8142-8160

3. Basu, A., Betts, N., Nguyen, A., Newman, E., Fu, D., Lyons, T.: Freeze-dried strawberries lower serum cholesterol and lipid peroxidation in adults with abdominal adiposity and elevated serum lipids. J Nutr. 2014; 144(6): 830-837

4. Nerurkar, PV.; Lee, Y.; Nerurkar, VR.: Momordica charantia (bitter melon) inhibits primary human adipocyte differentiation by modulating adipogenic genes. $B M C$ Complement Altern Med. 2010; 10:34-44

5. Obesity and overweight [http://www.who.int/mediacentre/factsheets/fs311/en/.]

6. Mitchell, N., Catenacci, V., Wyatt, H., Hill, J.: Obesity: overview of an epidemic. Psychiatr Clin North Am. 2011; 34(4): 717-732

7. Adult obesity facts [http://www.cdc.gov/obesity/data/adult.html]

8. Dee, A., Kearns, K., O’Neill, C. et al.: The direct and indirect costs of both overweight and obesity: a systematic review. BMC Research Notes. 2014; 7:242

9. National health and nutrition examination survey 1999-2014 survey content brochure [http://www.cdc.gov/nchs/data/nhanes/survey_content_99_14.pdf.]

10. Vaneckova, I., Maletinska, L., Behuliak, M. et al.: Obesity-related hypertension: possible pathopsychological mechanisms. J Endocrinol. 2014; 223: 63-78

11. Blokhin, I., Lentz, S.: Mechanisms of thrombosis in obesity. Curr Opin Hematol. 2013; 20(5): 437-444 
12. Llewellyn, C., Trzaskowski, M., van Jaarsveld, C. et al.: Satiety mechanisms in genetic risk of obesity. JAMA Pediatr. 2014 April; 168(4): 338-344

13. Menzo, E.: Biomarkers and obesity. J Mol Biomark Diagn. 2012; 103(2)

14. Vincent, H., Taylor, A.: Biomarkers and potential mechanisms of obesity-induced oxidant stress in humans. Int J Obes. 2006; 30: 400-418

15. Stepian, M., Stepian, A., Wlazel, RN., Paradowski, M., Banach, M., Rysz, J.: Obesity indices and inflammatory markers in obese non-diabetic normo- and hypertensive patients: a comparative pilot study. Lipids Health Dis. 2014; 13: 29-39

16. Kawano, J.; Arora, R.: The role of adinopectin in obesity, diabetes, and CVD. J Cardiometab Syndr. 2009; 4(1): 44-49

17. Abbasi, F., Chu, JW., Lamendola, C. et al.: Discrimination between obesity and insulin resistance in the relationship with adinopectin. Medscape J Med. 2004; 53(3): 585-590

18. Tome-Carniero, J., Gonzalvez, M., Larrosa, M. et al.: Grape resveratrol increases serum adiponectin and downregulates inflammatory genes in peripheral blood mononuclear cells: a triple-blind, placebo-controlled, one-year clinical trial in patients with stable Coronary Artery Disease. Cardiovasc Drugs Ther. 2013; 27: 37-48

19. Jowko, E.: Green tea catechins and sports performance. In Antioxidants in Sport Nutrition. Edited by Lamprecht M. Boca Raton (FL): CRC Press; 2015.

20. Suliburska, J.: Effects of green tea supplements on elements, total antioxidants, lipids and glucose values in the serum of obese patients. Biol Trace Elem Res. 2012; 149: 315-322

21. Basu, A., Betts, N., Mulugeta, A., Tong, C., Newman, E., Lyons, TJ. : Green tea supplementation increases glutathione and plasma antioxidant capacity in adults with the metabolic syndrome. Nutr Res. 2013; 33(3): 180-187

22. Tabesh, F., Sanei, H., Jahangri, M. et al: The effects of beta-glucan rich oat bread on serum nitric oxide and vascular endothelial function in patients with hypercholesterolemia. Biomed Res Int. 2014; 2014: 1-6

23. Oldewage-Theron, W.; Egal, A.: The effect of consumption of soy foods on the blood lipid profile of women: a pilot study from Qwa-Qwa. J Nutr Sci Vitaminol (Tokyo). 2013; 59(5): 431-436

24. Acheson, K., Zahorska-Markiewicz, B., Pittet, P., Anantharman, K., Jequier, E.: Caffeine and coffee: their influence on metabolic rate and substrate utilization in normal weight and obese individuals. Am J Clin Nutr. 1980; 33(5): 989-997

25. Drouin-Chartier, JP., Gigleux, I., Tremblay, AJ., Poirier, L., Lamarche, B., Couture, P.: Impact of dairy consumption on essential hypertension: a clinical study. Nutr J. 2014; 13 : 83-92

26. Jones, J., Provost, M., Laura, K., et al: A randomized trial on the effects of flavorings on the health benefits of daily peanut consumption. Am J Clin Nutr. 2013; 99(3): 490-496

27. Hongu N., Kitts, D., Zawistowski, J. et al: Pigmented rice bran and plant sterol combination reduces serum lipids in overweight and obese adults. J Am Coll Nutr. 2014; 33(3): 231-238

28. Ramprasath, V., Jenkins, D., Lamarche, B. et al: Consumption of a dietary portfolio of cholesterol lowering foods improves blood lipids without affecting concentrations of fat soluble compounds. Nutr J. 2014; 13:101-113 
29. Theuwissen, E.; Mensink, RP.: Simultaneous intake of beta-glucan and plant stanol esters affects lipid metabolism in slightly hypercholesterolemic subjects. J Nutr. 2007; 137(3): 583-588

30. Akaike, M., Ken-ichi, A., Hiroaki, Y. et al: Efficacy and safety of Citrus sudachi peel in obese adults: A randomized, double-blind, pilot study. FFHD. 2014; 4(6): 276-284

31. Weststrate, J.; van Poppel, G.; Verschuren, P.: Functional foods, trends and future. British Journal of Nutrition (2002), 88: 233-235

32. Nutrient content claims [http://www.fda.gov/Food/IngredientsPackagingLabeling/LabelingNutrition/ucm2006880 .htm.]

33. Bui, T., Le, TH., Nguyen, H. et al: Pre-germinated brown rice reduced both blood glucose concentration and body weight in Vietnamese women with impaired glucose tolerance. J Nutr Sci Vitaminol. 2014; 60(3): 183-187

34. Vásquez-Trespalacios, E., Romero-Palacio, J.: Efficacy of yogurt drink with added plant stanol esters (Benecol®, Colanta) in reducing total and LDL cholesterol in subjects with moderate hypercholesterolemia. Lipids Health Dis. 2014; 13:125-132

35. Sola, R., Valls, RM., Godas, G. et al: Cocoa, hazelnuts, sterols and soluble fiber cream reduces lipids and inflammation biomarkers in hypertensive patients: a randomized controlled trial. PLoS One. 2012; 7(2): 1-7

36. Akazome, Y., Kametani, N., Kanda, T., Shimasaki, H., Kobayashi, S.: Evaluation of safety off excessive intake and efficacy of long-term intake of beverage containing apple polyphenol. J Oleo Sci. 2010; 59(6): 321-338

37. Egert, S., Boesch-Saadatmandi, C., Wolffram, S., Rimbach, G., Muller, M.: Serum lipid and blood pressure responses to quercetin vary in overweight patients by apolipoprotein E genotype. J Nutr. 2010; 140(2):278-284

38. Augustine, A., Lowenstein, L., Harris, W., Shearer, G., Block, R.: Treatment with omega-3 fatty acid ethyl-ester alters fatty acid composition of lipoproteins in overweight or obese adults with insulin resistance. Prostoglandins leukot essent fatty acids. 2014; 90(3): 69-75

39. Oosterwerff, M., Eekhoff, EM., Van Schoor, NM. et al: Effect of moderate-dose vitamin D supplementation on insulin sensitivity in vitamin D-deficient non-Western immigrants in the Netherlands: a randomized placebo-controlled trial. Am J Clin Nutr. 2014; 100: 152-160

40. Xiao, S., Fei, N., Pang, X. et al: A gut microbiota-targeted dietary intervention for amelioration of chronic inflammation underlying metabolic syndrome. FEMS Microbiol Ecol. 2014; 87(2): 357-367

41. Basu, A., Du, M., Sanchez, K. et al: Green tea minimally affects biomarkers of inflammation in obese subjects with metabolic syndrome. Nutrition. 2011; 27(2): 206213

42. Venables, MC., Hulston, CJ., Cox, HR., Jeukendrup, AE. et al: Green tea extract ingestion, fat oxidation, and glucose tolerance in healthy humans. Am J Clin Nutr. 2008; 87(3): 778-784 
43. Brown, A., Lane, J., Coverly, J. et al: Effects of dietary supplementation with the green tea polyphenol epigallocatechin-3-gallate on insulin resistance and associated metabolic risk factors: randomized controlled trial. Br J Nutr. 2009; 101(6): 886-894

44. Maki, K., Reeves, M., Farmer, M. et al: Green tea catechin consumption enhances exercise- induced abdominal fat loss in overweight and obese adults. J Nutr. 2009; 139(2): 264-270

45. Hsu, C., Liao, Y., Lin, S., Tsai, T., Huang, C., Chou, P.: Does supplementation with green tea extract improve insulin resistance in obese type 2 diabetics? A randomized, double-blind, and placebo-controlled clinical trial. Altern Med Rev. 2011; 16(2): 157-163

46. Dulloo, A., Duret, C., Girardier, L. et al: Efficacy of a green tea extract rich in catechin polyphenols and caffeine in increasing 24-h energy expenditure and fat oxidation in humans. Am J Clin Nutr. 1999; 70(6): 1040-1045

47. OECD Health Statistics 2014 [www.oecd.org/health/healthdata.]

48. Farhangi, MA., Keshavarz, SA., Eshraghian, M., Ostadrahimi, A., Saboor-Yaraghi, A. et al: The effect of vitamin A supplementation on thyroid function in premenopausal women. J Am Coll Nutr. 2012; 31(4): 268-274

49. Mason, C., Xiao, L., Imayama, I. et al: Vitamin D3 supplementation during weight loss: a double-blind randomized controlled trial. Am J Clin Nutr. 2014; 99(5): 1015-1025

50. Murer, SB., Aeberli, I., Braegger, CP. et al: Antioxidant supplements reduced oxidative stress and stabilized liver function tests but did not reduce inflammation in a randomized controlled trial in obese children and adolescents. J Nutr. 2014; 144(2): 193-201

51. Iamopas, O, Ratanachu-ek, S., Chomotho, S.: Effect of folic acid supplementation on plasma homocysteine in obese children: a randomized, double-blind, placebo-controlled trial. J Med Assoc Thai. 2014; 97(6): 195-204

52. IDF Diabetes Atlas [http://www.idf.org/diabetesatlas/update-2014]

53. Cardiovascular Diseases [http://www.who.int/mediacentre/factsheets/fs317/en/.]

54. Epidemiology of hypertension [http://emedicine.medscape.com/article/1928048overview\#a2]

55. Worldwide cancer statistics [http://www.cancerresearchuk.org/healthprofessional/cancer-statistics/worldwide-cancer\#heading-Zero]

56. Narotzki, B., Reznick, A., Navot-Mintzer, D., Dagon, B., Levy, Y.: Green tea and vitamin Eenhance exercise-induced benefits in body composition, glucose homeostasis, and antioxidant status in elderly men and women. J Am Coll Nutr. 2013; 32(1): $31-40$

57. Fildes, A., Charlton, J., Rudisill, C., Littlejohns, P., Prevost, T., Guliford, M.: Probability of an obese person attaining normal body weight: cohort study using electronic health records. Am J Public Health. 2015; 105(9): 54-59 